\title{
PERMASALAHAN DALAM TRANSAKSI E-COMMERCE
}

\author{
Ida Kurnia ${ }^{1}$ dan Imelda Martinelli ${ }^{2}$ \\ ${ }^{1}$ Jurusan Ilmu Hukum, Universitas Tarumanagara Jakarta \\ Email: idah@fh.untar.ac.id \\ 2 Jurusan Ilmu Hukum, Universitas Tarumanagara Jakarta \\ Email: imeldam@fh.untar.ac.id
}

\begin{abstract}
sellers and buyers experience problems in e-commerce transactions and that causes is not understanding in details of legal provisions in the sale and purchase agreement that will be faced. In addition, people does not pay attention in the risks that can be occurs from buying and selling transaction via internet. One of the areas where people often experience various problems in e-commerce transactions are in Blok Duku RT 10/RW 10, Cibubur, East Jakarta area. One of the efforts taken to overcome this problem is to socialize the Law on Consumer Protection and provides tips for people around as a seller or buyers to understand the contents of the sale and purchase agreement, also understand the problems and risks that can be occur from e-commerce transaction. At this level, online socialization is needed. Within this activity, people around that area who once did not have a complete and clear knowledge of the problems in e-commerce transaction became understand. In addition, the target achievements will result that people around that area gets an adequate understanding in the safety of e-commerce transaction. The output of this activity will be form of article in journal publised by Universitas Tarumanagara. The socialization of this activity are carry out by survey methods, lectures, and question and answer sessions. Thus, people around that area could understand the risks to be faced and able to be feel safety in e-commerce transactions.
\end{abstract}

Keywords: Problems, Transaction, E-commerce.

\begin{abstract}
ABSTRAK
Pelaku usaha maupun konsumen banyak mengalami berbagai permasalahan dalam transaksi e-commerce dan hal yang sering menjadi penyebab adalah tidak memahami secara mendetail mengenai ketentuan hukum dalam perjanjian jual beli dan berbagai risiko-risiko yang akan dihadapi. Selain itu, masyarakat juga tidak memperhatikan risiko-risiko yang dapat terjadi dalam transaksi jual beli melalui media internet. Salah satu daerah yang masyarakatnya sering mengalami berbagai permasalahan dalam transaksi e-commerce adalah di daerah Blok Duku RT 10/ RW 10, Cibubur, JakartaTimur. Salah satu upaya yang ditempuh dalam mengatasi persoalan tersebut, yaitu melakukan sosialisasi Undangundang mengenai Perlindungan Konsumen dan memberikan kiat-kiat supaya masyarakat sebagai penjual ataupun pembeli memahami isi perjanjian jual beli dan mengetahui hak-haknya serta memahami masalah dan risiko yang dapat timbul dari transaksi e-commerce. Pada level ini diperlukan sosialisasi secara online. Melalui kegiatan ini, warga sekitar yang semula tidak mempunyai pengetahuan yang utuh dan jelas mengenai permasalahan dalam transaksi $e$ commerce menjadi paham. Selain itu, target capaian yang akan dihasilkan adalah masyarakat mendapatkan suatu pemahaman yang memadai berkenaan dengan transaksi $e$-commerce yang aman. Luaran kegiatan pengabdian kepada masyarakat ini berupa tulisan dalam artikel di jurnal yang diterbitkan oleh Universitas Tarumanagara. Pelaksanaan sosialisasi pengabdian kepada masyarakan ini dilaksanakan dengan metode survei, ceramah dan sesi tanya jawab. Dengan demikian, masyarakat dapat memahami akan risiko-risiko yang akan dihadapi sehingga dapat melakukan transaksi e-commerce yang aman.
\end{abstract}

Kata Kunci: Permasalahan, Transaksi, E-commerce

\section{PENDAHULUAN}

\section{Analisis Situasi}

Kasus positif Corona Virus Disease 2019 (yang selanjutnya disebut dengan COVID-19) di Indonesia pada tanggal 29 Januari 2021 sudah tembus 1 juta lebih kasus. Oleh karena itu, pemerintah menetapkan agar program Pembatasam Sosial Berskala Besar (yang selanjutnya disebut dengan PSBB) diterapkan pada beberapa daerah yang tergolong dalam zona merah, seperti di Jakarta. PSBB dapat dikatakan sebagai pembatasan aktivitas penduduk di suatu wilayah yang banyak terkena kasus COVID-19 untuk meminimalisir penyebaran COVID-19 yang semakin meluas. 


\section{Gambar 1}

Jumlah kasus Covid-19 di Indonesia pada Tanggal 29/01/2021 (JHU, 2021)

\begin{tabular}{|c|c|c|c|c|}
\hline $\begin{array}{l}\text { Kasus } \\
1,04 \mathrm{jt} \\
+13.695\end{array}$ & $\begin{array}{l}\text { Sembuh } \\
842 \mathrm{rb} \\
+10.792\end{array}$ & $\begin{array}{l}\text { Meninggal dunia } \\
29.331 \\
+476\end{array}$ & & \\
\hline Lokasi & & Kasus $_{\downarrow}$ & Sembuh & $\begin{array}{l}\text { Meninggal } \\
\text { dunia }\end{array}$ \\
\hline Jakarta & & $259 \mathrm{rb}$ & $232 \mathrm{rb}$ & 4.151 \\
\hline Jawa Barat & & $139 \mathrm{rb}$ & $110 \mathrm{rb}$ & 1.838 \\
\hline Jawa Tengah & & $122 \mathrm{rb}$ & 79.703 & 5.319 \\
\hline Jawa Timur & & $110 \mathrm{rb}$ & 94.397 & 7.639 \\
\hline Sulawesi Selatan & & 46.598 & 41.769 & 730 \\
\hline
\end{tabular}

Seiring bertambah banyaknya kasus positif yang terus naik, sebagai akibatnya Pemerintah menetapkan agar program PSBB terus dilaksanakan dan diperpanjang. Hal ini berdampak pada perekonomian seluruh kegiatan usaha di berbagai bidang. Anies Baswedan selaku Gubernur DKI Jakarta menetapkan bahwa pelaksanaan PSBB Ketat untuk wilayah DKI Jakarta diperpanjang sampai tanggal 8 Februari 2021. Namun, tidak menutup kemungkinan PSBB Ketat akan terus diterapkan dan diperpanjang apabila kasus tersebut tidak ada penurunan angka penularan virus corona.

Dengan semakin meningkatnya kasus COVID-19, aktivitas masyarakat saat ini sangatlah terhambat. Program PSBB mengatur agar jam operasional kerja diperpendek daripada jam kerja pada umumnya guna menurunkan angka penularan COVID-19, sehingga mengurangi aktivitas masyarakat. Namun, manusia tidak boleh terpuruk akan pembatasan untuk beraktivitas. Pengurangan aktivitas masyarakat di luar memberi dampak kepada masyarakat agar masyarakat dari berbagai usia terpaksa untuk beralih pada dunia teknologi yaitu internet. Segala sesuatunya beralih secara online, termasuk juga kegiatan transaksi $e$-commerce. Oleh karena itu, penggunaan dan pemanfaatan teknologi menyebabkan perubahan aktivitas manusia di berbagai bidang dan secara langsung berdampak pada lahirnya bentuk-bentuk proses hukum baru. Selain itu, hal ini mengakibatkan masyarakat secara tidak langsung dipaksakan untuk beradaptasi dengan dunia teknologi, yang menyebabkan pembelanjaan kebutuhan sehari-hari beralih secara online.

E-commerce adalah istilah yang mengacu pada tindakan yang dilakukan dengan jaringan komputer dan/atau media elekronik lainnya. Dalam hal ini banyak masyarakat yang melakukan transaksi $e$ commerce untuk pemenuhan kebutuhan sehari-harinya. Dewasa ini karena semakin banyak orangorang menggunakan transaksi elektornik seperti e-commerce, banyak oknum-oknum tertentu memanfaatkan hal tersebut untuk melakukan kejahatan secara online. Kejahatan tersebut kerap disebut dengan cybercrime atau kejahatan siber, yang mana hal ini termasuk tindakan kejahatan dengan menggunakan teknologi komputer dan internet untuk memperoleh keuntungan disamping membuat pihak lain rugi atas tindakannya. Salah satu contoh kejahatan yang dilakukan dalam $e$ commerce adalah penipuan. 
Transaksi e-commerce juga merupakan bentuk kesepakatan antar pelaku usaha dengan konsumen dalam melakukan pembelian secara online. Kesepakatan tersebut bisa disebut sebagai sebuah perjanjian jual beli yang menimbulkan hak dan kewajiban yang harus dipenuhi. Dalam hal ini, pelaku usaha berkewajiban memberikan barang yang bagus dan sesuai pesanan konsumen dan berhak untuk menerima uang atas pembayarannya. Sedangkan konsumen berkewajiban untuk membayar sejumlah uang atas apa yang dipesannya dan berhak untuk menerima barang yang dipesan dengan kondisi yang baik.

Pelaksanaan transaksi elektornik ini dapat menggunakan berbagai macam cara. "Beberapa tahapannya antara lain:

a. Penawaran melalui media internet atau akun e-commerce yang dilakukan oleh pelaku usaha.

b. Penerimaan penjualaan dari konsumen dapat dilakukan tergantung dari ketertarikan konsumen pada penawaran yang diberikan.

c. Pembayaran dapat dilakukan dengan berbagai cara seperti transfer bank atau bayar ditempat (COD).

d. Pengiriman dilakukan oleh pelaku usaha ke tempat konsumen setelah pemesanan dan pemilihan metode pembayaran atas barang yang ditawarkan karena konsumen berhak menerima barang yang telah dipesan dan sesuai"

Konsekuensi dari berkembangnya e-commerce ditengah masyarakat telah memberikan sebuah dampak yang positif maupun negatif. Bahwa dampak positif adanya transaksi e-commerce memberikan kemudahan dan praktis bagi pelaku usaha untuk menawarkan barang-barang yang dijual kepada konsumen secara online tanpa harus konsumen datang langsung ke toko. Selain itu, terdapat pula dampak negatif dalam hal keamanan berbelanja online yang dapat merugikan kedua belah pihak dan secara hukum hal ini terkait dengan adanya perlindungan hukum dan jaminan kepastian hukum dalam bertransaksi di e-commerce. Perlu dipahami beberapa permasalahan dalam transaksi e-commerce, yaitu:

a. Barang yang diterima oleh konsumen tidak sesuai, dalam arti penjual lalai mengirim barang yang sesuai dengan yang dipesan oleh konsumen.

b. Potensi adanya penipuan yang mana konsumen gagal menerima barang dari penjual padahal telah melakukan pembayaran.

c. Adanya tawaran atau diskon palsu yang menggiurkan supaya menjebak konsumen untuk membeli barang yang ada.

d. Potensi adanya hacker (peretas) yang mengambil alih akun e-commerce konsumen untuk mengambil data atau menggunakan akun tersebut untuk hal yang tidak baik sehingga merugikan konsumen.

Pada prinsipnya, transaksi e-commerce dapat dikatakan seperti transaksi jual beli yang ada pada umumnya, tetapi hal yang membedakan yaitu kalau transaksi ini menggunakan media online sehingga keamanan dalam transaksi e-commerce sering menjadi masalah utama. Salah satunya dalam bentuk penipuan. Penipuan ini dapat dilakukan oleh banyak oknum yang berbeda, baik pelaku usaha ataupun konsumen yang buruk.

Salah satu jenis kejahatan komputer adalah penipuan. Bentuk penipuan ini menjadi semakin populer. Secara khusus, banyak orang ingin dengan mudah memenuhi kebutuhan mereka dan menghemat waktu dan uang. Kegiatan tersebut bersifat online, tetapi dapat dikategorikan sebagai tindakan dan proses nyata. Penipuan ini adalah penjahat dunia maya yang memanfaatkan kelemahan dan kebiasaan keamanan saat menggunakan Internet. 
Penipuan online pada dasarnya sama dengan penipuan tradisional. Perbedaannya hanya pada sarana tindakan penggunaan sistem elektronik seperti komputer, internet, peralatan telekomunikasi lainnya. Oleh karena itu, secara hukum, penipuan online dapat diperlakukan dengan cara yang sama seperti kegiatan pidana yang diatur oleh KUHP. Berdasarkan hal tersebut di atas dan berdasarkan pengamatan yang telah dilakukan, maka daerah Jalan Blok Duku RT 10/10, Cibubur, Jakarta-Timur sangat potensial untuk dilakukan sosialisasi tentang cara melakukan dalam UU No. 11 Tahun 2008 tentang Informasi dan Transaksi Elektronik tidak secara khusus mengatur kegiatan penipuan. Tindak pidana penipuan sendiri diatur dalam Pasal 378 KUHP.

Selain itu, Pasal 4, 5, 6, 7 Undang-Undang Nomor 8 Tahun 1999 tentang Perlindungan Konsumen menyatakan bahwa pelaku usaha dan konsumen dalam bertransaksi memiliki hak-hak dan kewajiban yang harus dilakukan. Disamping itu juga, diatur larangan-larangan yang tidak boleh dilakukan oleh pelaku usaha. Oleh karena itu, dengan melaksanakan hak dan kewajiban tersebut masyarakat dapat memenuhi transaksi e-commerce yang aman. Berdasarkan hal di atas dan pengamatan yang dilakukan, Jalan Blok Duku RT 10/10, Cibubur di wilayah Jakarta Timur memiliki peluang yang besar untuk dilakukan sosialisasi tentang permasalahan dalam e-commerce dan bagaimana cara transaksi e-commerce yang aman. Target ini dikhususkan untuk warga RT 10/RW 10, Blok Duku RT 10/RW 10, dan Cibubur di Jakarta Timur.

Proses sosialisasi diperlukan supaya pelaku usaha dan konsumen mengerti akan bahaya-bahaya dan risiko dari transaksi e-commerce, serta perlindungan hukumnya. Dengan adanya sosialisasi ini, diharapkan agar warga Blok Duku RT 10/ RW 10, Cibubur, Jakarta Timur bisa melaksanakan kegiatan transaksi e-commerce yang benar dan aman. Oleh karena itu, para warga RT dan RW Blok Duku RT 10/ RW 10, Cibubur, Jakarta-Timur, Prov. DKI Jakarta, perlu memahami permasalahan tersebut. Dengan demikian, warga dapat melakukan transaksi $e$-commerce dengan aman.

\section{Permasalahan Mitra}

Hal utama yang sering menjadi penyebab pelaku usaha maupun konsumen banyak mengalami permasalahan dalam transaksi e-commerce yaitu kurang mengerti atau memahami secara mendetail informasi yang dituangkan oleh pelaku usaha dan resiko-resiko yang mungkin dihadapi sebelum konsumen melakukan transaksi e-commerce dengan pelaku usaha serta ketentuan hukum dalam perjanjian jual beli. Selain itu, pengguna e-commerce sering tidak memperhatikan hal-hal keamanan dalam transaksi online. Sehingga, pengguna dalam hal ini masyarakat sering mengalami permasalahan dalam transaksi e-commerce.

Penyuluhan yang diberikan kepada masyarakat di daerah Blok Duku RT 10/ RW 10, Cibubur, Jakarta Timur karena daerah tersebut masyarakatnya masing sering mengalami permasalahan dalam transaksi online, salah satunya melalui e-commerce. Permasalahan tersebut antara lain barang yang tidak sesuai, adanya kerusakan barang, pengiriman yang lama dan tidak diterima oleh konsumen, pernah mengalami penipuan dalam belanja online dan lain sebagainya. Oleh sebab itu, sosialisasi hukum yang diberikan secara online kepada masyarakat setempat sangat diperlukan. Selanjutnya, masyarakat pada daerah ini masih sangat awam terhadap pemahaman mengenai perjanjian jual beli. Sehingga pengetahuan dan pemahaman perjanjian jual beli perlu juga diberikan sebagai bentuk pencegahan dari permasalahan yang sering terjadi.

\section{Solusi Mitra}

Bahwa konsumen atau pembeli dalam melakukan belanja online melalui transaksi e-commerce perlu mendapat perlindungan hukum, supaya konsumen dapat merasa aman dan nyaman serta 
tidak mengalami kerugian yang timbul akibat permasalahan yang sering terjadi. Oleh karena itu, pemerintah harus tegas memberikan perlindungan konsumen melalui diterapkannya semaksimal mungkin undang-undang perlindungan konsumen dan memberikan langkah-langkah dalam mencegah dan mengatasi permasalahan yang dapat terjadi dalam transaksi online. Selain itu, diperlukannya sosialisasi secara langsung atau online dengan kondisi Jakarta yang sedang terserang wabah COVID-19 kepada masyarakat supaya masyarakat sebagai pelaku usaha maupun konsumen mengerti isi perjanjian jual beli dan mengetahui hak-haknya serta mengerti masalah yang dapat timbul dari transaksi e-commerce. Pada level ini diperlukan sosialisasi secara online di wilayah Blok Duku RT 10/ RW 10, Cibubur, Jakarta Timur.

Masyarakat di daerah Blok Duku RT 10/ RW 10, Cibubur, Jakarta Timur tersebut di atas dipandang sebagai target yang tepat untuk mendapatkan sosialisasi perlindungan konsumen terkait transaksi e-commerce, karena masyarakat disini sering kali mengalami permasalahan dalam bertransaksi online. Konsumen yang memilih belanja online karena praktis dan mudah tanpa harus ke toko langsung, kerap juga mengalami kerugian atas transasi di e-commerce. Selanjutnya, dengan adanya solusi ini, masyarakat di daerah tersebut kedepannya akan lebih berhati-hati dalam transaksi e-commerce dan tidak diam saja ketika mengalami kerugian maupun permasalahan lainnya, tetapi bisa dengan tepat dan cepat melakukan tindakan pencegahan penyelesaian permasalahan sehingga tidak akan menjadi pihak yang dirugikan.

Dengan dilaksanakannya penyuluhan ini, diharapkan program ini dapat memberikan solusi dan jaminan kepastian dan pelindungan hukum yang nyata, yakni terwujudnya transaksi e-commerce yang aman. Selain itu juga, masyarakat sebagai pembeli ataupun penjual dapat memahami aturanaturan tentang perlindungan konsumen serta dapat menjadi penjual dan pembeli yang memahami risiko yang akan dihadapi serta perlindungan hukumnya. Pada akhirnya masyarakat di daerah Blok Duku RT 10/ RW 10, Cibubur, Jakarta-Timur akan merasa aman dalam bertransaksi melalui $e$ commerce.

\section{METODE PELAKSANAAN PKM}

\section{Tahap Awal}

Tahap awal kegiatan pengabdian kepada masyarakat dilaksanakan terlebih dulu dilakukan survei dengan tetap memperhatikan protokol kesehatan di daerah Blok Duku RT 10/ RW 10, Cibubur, Jakarta Timur. Dalam survei, Tim PKM menemui Ketua RT 10/ RW 10, dan diperoleh keterangan bahwa di wilayah tersebut sering terjadi/ mengalami berbagai kendala dan permasalahan dalam transaksi e-commerce yang membuat masyarakat sekitar menjadi resah.

Koordinasi dengan Ketua RT, Ketua RW, Lurah Blok Duku RT 10/ RW 10, Cibubur, Jakarta Timur. Kegiatan ini dilakukan untuk tidak menghilangkan peran Lurah, Ketua RW, Ketua RT dalam memberikan materi perlindungan hukum dan kepastian hukum terhadap warga yang merupakan pembeli dan penjual dalam transaksi e-commerce.

\section{Tahap Pelaksanaan}

\section{Ceramah}

Pelaksanaan pengabdian kepada masyarakat ini dilakukan secara online melalui media teleconference, yaitu Zoom. Metode yang digunakan berupa ceramah yang dilakukan oleh pemateri guna memberikan informasi dan solusi secara mendalam berkenaan dengan permasalahan transaksi e-commerce. 
Sosialisasi dilakukan dengan cara memberikan penjelasan mengenai pengaturan-pengaturan dalam bertransaksi e-commerce, yaitu dalam perspektif undang-undang terkait dalam permasalahan yang dibahas. Selain itu, bentuk-bentuk pencegahan dan kiat-kiat transaksi yang aman dalam belanja online di e-commerce.

Pemaparan materi dalam kegiatan PKM ini memuat hukum transaksi e-commerce. Penyuluhan dilakukan dalam bentuk ceramah dan diskusi dua arah secara mendalam di wilayah Blok Duku RT 10/ RW 10, Cibubur, Jakarta Timur. Sosialisasi mengenai pemahaman tentang Undang-undang tentang Perlindungan Konsumen, Undang-undang tentang Informasi dan Transaksi Elektronik juga diberikan untuk menjadi bahan acuan secara berkelanjutan dalam memahami transaksi elektronik dan perlindungan konsumen.

\section{Questions and Answers (Q \& A)}

Setelah dilakukan ceramah secara online selesai, selanjutnya digunakan metode Q \& A. Dengan metode ini warga di daerah Blok Duku RT 10/ RW 10, Cibubur, Jakarta Timur diberi kesempatan untuk mengajukan pertanyaan. Pertanyaan tersebut dijawab oleh Tim PKM.

\section{HASIL DAN PEMBAHASAN}

Kegiatan Pengabdian Kepada Masyarakat dilaksanakan dengan survey terlebih dahulu dan tetap memperhatikan protokol kesehatan di daerah Blok Duku RT 10/RW 10, Cibubur, Jakarta-Timur. Hal ini dilakukan dalam rangka mematuhi peraturan pemerintah dan menjaga tidak tersebarnya virus covid. Pertama-tama yang dilakukan oleh Tim PKM menemui Ketua RT 10/RW 10, dari hasil pembicaraan diperoleh informasi bahwa di wilayah Blok Duku RT 10/RW 10, Cibubur, Jakarta-Timur sering terjadi/ mengalami berbagai kendala dan permaslahan dalam transaksi $e$ commerce yang membuat masyarakat wilayah Blok Duku RT 10/RW 10, Cibubur, Jakarta-Timur menjadi resah, terkait dengan adanya kejahatan-kejahatan yang terkait dengan transaksi $e$ commerce.

Selanjutnya, tim PKM berinisiatif untuk mengadakan penyuluhan, pembinaan dan pendidikan terkait dengan hal tersebut. Perlu disampaikan pada kesempatan ini bahwa setelah diadakannya penyuluhan hukum tentang transaksi e-commerce dan permasakahannya, antusias peserta penyuluhan sangat responsif. Hal ini terlihat dari peserta yang disuluh aktif dalam mengajukan pertanyaan-pertanyaan pada saat menyampaikan permasalahan yang dihadapinya.

Pada saat tim penyuluh memaparkan materi, para peserta juga menanyakan materi seputar perlindungan konsumen/ apakah yang harus diperhatikan pembeli/ penjual dalam transaksi $e$ commerce, supaya pembeli dan penjual dapat merasakan aman. Dengan adanya pertanyaan tersebut, kemudian dijelaskan secara mendetail oleh tim PKM mengenai transaksi e-commerce merupakan bentuk kesepakatan antar pelaku usaha dengan konsumen dalam melakukan pembelian secara online. Kesepakatan tersebut bisa disebut sebagai sebuah perjanjian jual beli yang menimbulkan hak dan kewajiban yang harus dipenuhi. Dalam hal ini, pelaku usaha berkewajiban memberikan barang yang bagus dan sesuai pesanan konsumen dan berhak untuk menerima uang atas pembayarannya. Sedangkan konsumen berkewajiban untuk membayar sejumlah uang atas apa yang dipesannya dan berhak untuk menerima barang yang dipesan dengan kondisi yang baik.

Kegiatan PKM dengan Tema "Permasalahan Dalam Transaksi E-commerce" menitikberatkan pada pemberian pemahaman kepada masyarakat di daerah Blok Duku RT 10/RW 10, Cibubur, Jakarta Timur mengenai berbagai permasalahan dalam transaksi e-commerce dan pengenalan Undang-undang ITE dan Undang-undang Perlindungan Konsumen. Penyuluhan hukum 
dilaksanakan secara online melalui media teleconference yaitu zoom. Di dalam kegiatan PKM ini, masyarakat sangat aktif dan semangat untuk berdiskusi dan mengetahui lebih dalam permasalahan yang sering terjadi dalam transaksi e-commerce, dikarenakan masyarakat daerah Blok Duku RT 10 / RW 10, Cibubur, Jakarta Timur masih banyak belum paham dan mengerti mengenai bahayabahaya dalam transaksi e-commerce serta hak-haknya sebagai konsumen yang perlu mendapat perlindungan. Sehingga, dengan diadakan kegiatan PKM, masyarakat dapat mengetahui kewajiban dan haknya dalam bertransaksi e-commerce serta tidak mudah mengalami kerugian. Setelah dilakukannya kegiatan pengabdian kepada masyarakat berupa ceramah dan diskusi tanya jawab mengenai "Permasalahan Dalam Transaksi E-commerce" yang diikuti dengan kegiatan sosialisasi, pembinaan dan pendidikan terhadap warga Blok Duku RT 10/ RW 10, Cibubur, Jakarta Timur yang semula tidak mempunyai pengetahuan yang utuh dan jelas mengenai permasalahan dalam transaksi e-commerce menjadi paham.

Dalam pelaksanaaannya kegiatan ini menghasilkan beberapa hal sebagai berikut:

a. Masyarakat mendapatkan pemahaman yang baru dalam mengetahui hal-hal yang dapat terjadi dalam transaksi e-commerce.

b. Masyarakat lebih paham lagi bagaimana mengatasi permasalahan yang terjadi ketika menimpa dirinya.

c. Masyarakat sekitar lebih mengerti mengenai aspek hukum perlindungan konsumen dalam bertransaksi e-commerce baik dalam Undang-undang Nomor 8 Tahun 1999 tentang Perlindungan Konsumen dan Undang-undang Nomor 19 Tahun 2016 tentang Perubahan Atas Undang-undang Nomor 11 Tahun 2008 tentang Informasi Dan Transaksi Elektronik.

d. Masyarakat mendapatkan pemahaman mengenai upaya - upaya melakukan transaksi $e$ commerce yang aman.

\section{KESIMPULAN DAN SARAN}

a. Kesimpulan

Dengan diadakannya kegiatan pengabdian kepada masyarakat yang bertemakan "Permasalahan Dalam Transaksi E-commerce", Masyarakat Blok Duku RT 10/ RW 10, Cibubur, Jakarta Timur telah memahami berbagai permasalahan yang sering terjadi ketika melakukan transaksi e-commerce sehingga masyarakat dapat mewaspadai bahaya yang dapat terjadi dan ke depannya masyarakat bisa dengan aman melakukan transaksinya.

b. Saran

Banyaknya kasus yang terjadi di daerah Blok Duku RT 10/ RW 10, Cibubur, Jakarta Timur masih diperlukan penyuluhan lanjutan.

\section{Ucapan Terima Kasih (Acknowledgement)}

Sehubungan dengan telah dilaksanakannya kegiatan pengabdian kepada masyarakat berupa ceramah dan diskusi tanya jawab mengenai "Permasalahan Dalam Transaksi E-commerce", Tim PKM Fakultas Hukum Universitas Tarumanagara mengucapkan terima kasih kepada Lembaga Penelitian dan Pengabdian Kepada Masyarakat Universitas Tarumanagara, dan Ketua RT 10/ RW 10 Blok Duku, Cibubur, Jakarta Timur, Kota Administrasi Jakarta Timur, Prov. DKI Jakarta yang telah memberi izin kepada Tim PKM Fakultas Hukum Universitas Tarumanagara untuk mengadakan pengabdian kepada masyarakat di wilayahnya.

\section{REFERENSI}

Abidin, DZ, (2015). "Kejahatan dalam Teknologi Informasi dan Komunikasi". Jurnal Ilmiah Media Processor, 10(2), 509-516. 
Dewi, SAK. (2015). Perjanjian Jual Beli Barang Melalui Elektronik Commerce (E-Com). Jurnal Ilmiah Teknologi dan Informasia. IX(2), 1-5.

Indonesia. Peraturan Menteri Kesehatan Nomor 9 Tahun 2020 tentang Pedoman Pembatasan Sosial Berskala Besar Dalam Rangka Pencepatan Penanganan Corona Virus Disease 2019. Indonesia. Undang-undang Nomor 8 Tahun 1999 tentang Perlindungan Konsumen.

Indonesia. Undang-undang Nomor 11 Tahun 2008 tentang Informasi dan Transaksi Elektronik. Putra, MD. (2019). "Jual Beli Online Berbasis Media Sosial dalam Perspektif Ekonomi Islam”. Iltizam Journal of Shariah Economic Research, III(1), 83-103.

Sumenge, Melisa Monica. (2013). "Penipuan Mengunakan Media Internet Berupa Jual Beli Online”. Jurnal Lex Crimen, II(4), 102-112.

JHU CSSE COVID-19 Data, 2021 